Research Article

\title{
Numerical Study of the Performance and Emission of a Diesel-Syngas Dual Fuel Engine
}

\author{
Shiquan Feng \\ Merchant Marine College, Shanghai Maritime University, Shanghai, China \\ Correspondence should be addressed to Shiquan Feng; fengshiquan@outlook.com
}

Received 11 May 2017; Revised 18 September 2017; Accepted 28 September 2017; Published 25 October 2017

Academic Editor: Anna Vila

Copyright (C) 2017 Shiquan Feng. This is an open access article distributed under the Creative Commons Attribution License, which permits unrestricted use, distribution, and reproduction in any medium, provided the original work is properly cited.

\begin{abstract}
Based on the theory of direct relation graph (DRG) and the sensitivity analysis, a reduced mechanism for the diesel-syngas dual fuel was constructed. Three small thresholds were applied in the process of the detailed mechanism simplification by DRG, and a skeletal mechanism with 185 elements and the 832 elementary reactions was obtained. According to the framework of the skeletal mechanism, the time-consuming approach of sensitivity analysis was employed for further simplification, and the skeletal mechanism was further reduced to the size of 158 elements and 705 reactions. The Chemkin software with the detailed mechanism was utilized to calculate the effect of syngas addition on the combustion characteristics of diesel combustion. The findings showed that the addition of syngas could reduce the ignition delay time and increase the laminar flame speed. Based on the reduced mechanism and engine parameters, a 3D model of the engine was constructed with the Forte code. The 3D model was adopted to study the effect of syngas addition on the performance and exhaust emissions of the engine and the relevant data of the experiment was used in the calibration of the 3D model.
\end{abstract}

\section{Introduction}

Biomass is an environmental friendly renewable resource. The vaporization or fermentation of different types of biomass will produce hydrogen-rich syngas, which can be utilized as primary fuel for engine or partial substitute for conventional fuel. Consequently, carbon dioxide emission can be reduced effectively by the combination of the syngas generation process through biomass fermentation and syngas addition to the engine, as carbon mainly comes from biomass. The approach of such combination is particularly attractive in power plants and other places with stationary combustion equipment [1-4]. Actually, syngas can be generated from a lot of raw materials, including biomass fermentation, methane steam reforming, ethanol steam reforming, autothermal reforming of fossil fuel, partial oxidation of methane, ammonia cracking, and so forth, and the components of syngas obtained from different materials and devices may vary greatly. Hydrogen, carbon monoxide, carbon dioxide, methane, and nitrogen are the main constituents of syngas [5]. Due to the poor performance of syngas' autoignition, a small amount of diesel is injected into the cylinder of the engine to ignite the syngas. Sahoo et al. [6-8] studied the effect of the ratio of $\mathrm{H}_{2}$ and $\mathrm{CO}$ in syngas on the combustion of a diesel engine. They found that the combustion efficiency of the diesel engine was improved with the increase of hydrogen content. Syngas containing more hydrogen would cause higher cylinder pressure and cylinder temperature due to the high flame speed and high calorific value of hydrogen. The higher cylinder temperature would increase $\mathrm{NO}_{x}$ emission, and emissions of CO and HC were reduced as the addition of hydrogen could result in full combustion in the cylinder. On the other hand, syngas containing more CO could increase the $\mathrm{CO}$ emission in the exhaust gas. The effects of different biodiesel injection pressures and injection amounts on the power output of a biodiesel-syngas engine and the related emissions have been reported by Carlucci et al. [9]. A higher biodiesel injection pressure presented a better dispersion and penetration of the spray, and more zone of the cylinder could be reached by the flame of the biodiesel combustion, leading to an increase in the engine's combustion efficiency. The improved combustion of higher biodiesel injection pressure resulted in a reduction of THC and CO emissions, whereas an opposite behavior of $\mathrm{NO}_{x}$ and $\mathrm{CO}_{2}$ could be observed. With an increase of injected biodiesel amount, the cylinder 
pressure and temperature increased. As for the tailpipe emissions, an increase of $\mathrm{NO}_{x}$ and $\mathrm{CO}_{2}$ could be observed, while THC and CO were decreased. Azimov et al. [10] developed a reduced mechanism with only one reaction for the combustion of diesel and a 3D model to simulate the combustion of syngas in a diesel engine. The simulated in-cylinder temperature, pressure, and rate of heat release were compared with the experiment; good agreement could be observed at the equivalence ratio of 0.8 . The effect of removing the $\mathrm{H}_{2} \mathrm{O}_{2}$ related reactions was investigated through the analysis of the contribution to the heat releasing. It was found that $\mathrm{H}_{2} \mathrm{O}_{2}$ was an important element in the mechanism. All the simulation and the experiment were conducted under lean conditions, and the result showed that syngas addition could help the engine by reducing pollution. Hernández et al. [11, 12] have tested the performance of the combination of syngas generation through the gasification of dealcoholized marc of grape from winery and syngas addition in a diesel engine. Different replacements of diesel by syngas with different engine loads were studied. A decrease of PM and $\mathrm{NO}_{x}$ was observed while an increase of hydrocarbon and carbon monoxide was observed. Zhang et al. [13] conducted a twodimensional detailed numerical simulation to study the syngas/air combustion under the partially premixed combustion engine conditions, discovering that $\mathrm{NO}$ was produced mainly in the premixed burn region and later from the diffusion burn region in mixtures close to stoichiometry, whereas the unburned $\mathrm{CO}$ emission was mainly from the diffusion burn region. The effect of different compositions of syngas on the laminar flame speed was analyzed by Dong et al. [14] with the usage of a Bunsen burner. The results showed that, with the increase of $\mathrm{H}_{2}$ fraction in syngas, the laminar flame speed rose. Other types of researches related to the onboard syngas generation from ethanol/methanol steam reforming were reported by $\mathrm{Li}$ et al. [15-17] who noticed that catalyst played a key role in the syngas generating reactions.

There are a lot of reduced mechanisms for diesel combustion. However, reduced mechanism focusing on the interaction of syngas and diesel is rare. And very few CFD simulations have been conducted on the diesel-syngas dual fuel engine. The objective of this study is to develop a reduced mechanism focusing on the effect of syngas addition and construct a $3 \mathrm{D}$ engine model. As a calibration of the $3 \mathrm{D}$ simulation, the result of the simulation was compared with the corresponding experiment.

\section{Development of the Reduced Mechanism and the 3D Engine Model}

The common utilization of the syngas is to mount a syngas injector at the air intake manifold and let the syngas mix with air. And then the syngas-air mixture will be drawn into the cylinder together, as described in Figure 1.

2.1. Construction of the Reduced Mechanism. Although a lot of n-heptane reduced mechanisms have been developed to simulate the combustion of diesel, very few of them focus on the influence of syngas addition. Consideration should be given to the addition of syngas since they can influence the

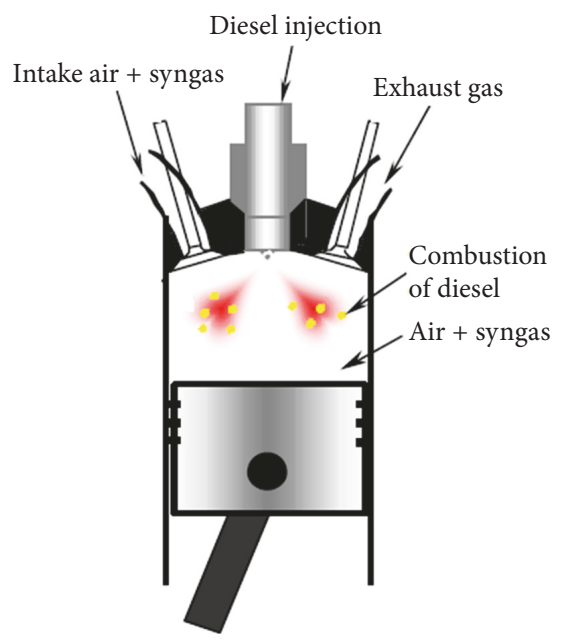

FIGURE 1: Schematic of combustion in cylinder.

performance of the diesel engine. To simulate the combustion in diesel-syngas dual fuel engine, a reduced mechanism was developed by the DRG method $[18,19]$ and the sensitivity analysis emphasizing the interaction of diesel and syngas. The detailed mechanism of Lawrence Livermore National Laboratory [20, 21] (detailed mechanism) with 654 elements and 2827 reactions was utilized as the base mechanism of the DRG reduction process. The parameters of the simulation in Chemkin software were set according to the actual working condition of diesel engine; the syngas consumption was $1 \mathrm{~kg} / \mathrm{h}$, the air consumption was $21 \mathrm{~kg} / \mathrm{h}$; the engine worked at $1500 \mathrm{rpm}$ with $15.5 \mathrm{kw}$ of power output and n-C7H16, $\mathrm{H}_{2}, \mathrm{CO}$, $\mathrm{CO}_{2}, \mathrm{CH}_{4}$, and $\mathrm{OH}$ radical as the initial-searching elements of DRG. According to previous studies, during the process of the mechanism simplification of a detailed mechanism by DRG, step by step reduction with several smaller thresholds was proved to be much more effective than step reduction with a bigger one [22-24].

Usually, an empirical threshold is used to develop a reduced mechanism first, and then the validation of the reduced mechanism is conducted by the comparison of the simulation result and experiment or other researchers' reduced mechanism on ignition delay time, laminar flame speed, important species, heat releasing rate, and so forth. In this study, the closed homogenous reactor in Chemkin software was adopted to calculate the ignition delay time with the reduced mechanism. The specified tolerance of the ignition delay time predicted by the reduced mechanism was less than $30 \%$ of the prediction by the detailed mechanism. That is, under these conditions, the prediction error of the ignition delay time with the reduced mechanism was no more than $30 \%$. Conditions of the simulation were as follows: six initial temperature of $700 \mathrm{~K}, 800 \mathrm{~K}, 900 \mathrm{~K}, 1000 \mathrm{~K}, 1100 \mathrm{~K}$, and $1200 \mathrm{~K}$, the pressure is $20 \mathrm{~atm}$, and the equivalent ratio is 1.

A threshold of 0.1 was adopted first to obtain a skeletal mechanism of 353 elements and 1753 reactions. Later, a threshold of 0.15 was used, and the skeletal mechanism was reduced to 271 elements and 1362 reactions. Finally, a threshold of 0.22 was utilized to gain a skeletal mechanism of 185 


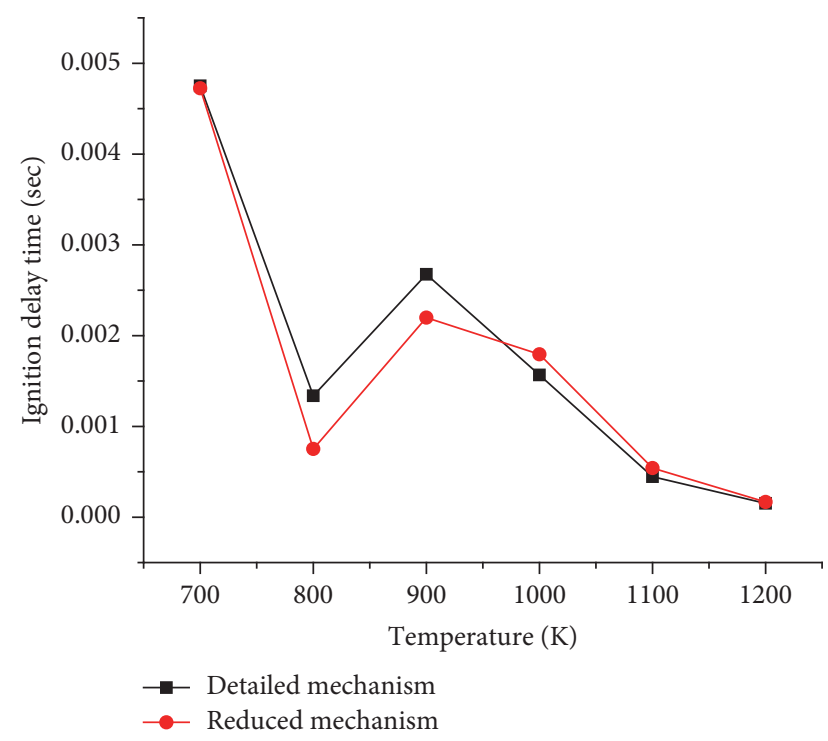

Figure 2: Comparison of ignition delay time by detailed and reduced mechanism.

elements and 832 reactions. If DRG process continued, the predicted value of the ignition delay time by the skeletal mechanism would exceed $30 \%$, and then the DRG process was stopped.

In some cases, a group of elements would be removed by DRG simultaneously as they had a very strong connection. As the removal of this group, the induced error of the predicted ignition delay time would increase dramatically. Usually, only a few elements of this group were responsible for the noticeable amount of the prediction error of the ignition delay time, while the rest of this group could be removed safely under the specified tolerance level. Thus, after reduction process of DRG, a reduction process of the sensitivity analysis was carried out to obtain a smaller reduced mechanism, as the two types of elements of the group were treated separately by the sensitivity analysis reduction. Each element of the skeletal mechanism was removed individually by the sensitivity analysis, and the induced error on the targeted ignition delay time was calculated. With the calculated error increased from the smallest to the biggest, the elements could be ranked in an ascending order. Later, the element was removed one by one from the smallest error and then the cumulative induced error was calculated. The removing process was stopped once the cumulative induced error was beyond the tolerance level. A reduced mechanism of 158 elements and 705 reactions was developed by the sensitivity analysis. Figure 2 shows the comparison of the ignition delay time between the detailed mechanism of the Lawrence Livermore National Laboratory and the reduced mechanism. The reduced mechanism showed good agreement with the detailed mechanism.

The formation mechanism of $\mathrm{NO}_{x}$ was not included in the detailed mechanism of Lawrence Livermore National Laboratory.

To predict the $\mathrm{NO}_{x}$ emission, the formation mechanism of $\mathrm{NO}_{x}$ was added to the reduced mechanism [25]. Four $\mathrm{NO}_{x}$ formation mechanisms were identified widely, including the thermal NO route $[26,27]$, the prompt NO route by Fenimore [28], the $\mathrm{NO}$ generated via $\mathrm{N}_{2} \mathrm{O}$ [29], and the conversion of fuel-nitrogen into NO [30]. The thermal NO route by Zeldovich with 4 elements and 12 reactions presented in Table 1 was added to the reduced mechanism.

$$
\text { Calculation of reaction rate: } k_{f}=A_{f} T^{n f} \exp \left(-E_{f} / R T\right) \text {. }
$$

The most significant reactions were reactions $1-4$, reactions 5-9 were the reaction of $\mathrm{N}_{2} \mathrm{O}$, and reactions $10-12$ were the interaction of $\mathrm{NO}$ and $\mathrm{NO}_{2}$.

The constructed reduced mechanism was added to this paper as the Supplementary Material (see Supplementary Material available online at https://doi.org/10.1155/2017/ 6825079).

2.2. Engine Model. The simulations were based on a single cylinder, four-stroke, and common-rail diesel engine [9]. The parameters of the engine are presented in Table 2, and the injection parameters are presented in Table 3.

$3 \mathrm{D}$ simulation of the diesel engine in the Forte code began at intake valve closing and ended at exhaust valve opening without any mass exchange with the outside. No chemical reaction was activated before the diesel injection, for the autoignition for the syngas-air mixture was very difficult. In the simulation model, the chemical reaction was activated after the diesel injection and the temperature of the dieselsyngas-air mixture inside the cylinder reached $600 \mathrm{~K}$. The cylinder head and the cylinder wall temperature were set to $400 \mathrm{~K}$ and the piston initial temperature was set to $500 \mathrm{~K}$. The cylinder wall heat loss was calculated by the model developed by Han and Reitz [31], and the atomization and droplet breakup of sprays were modeled by the Kelvin-Helmholtz/ Rayleigh-Taylor (KH/RT) [32] hybrid model. Herein, the KH breakup model was applied within a specified breakup length. It striped small droplets off the jet, yet the jet still maintained itself as a dense liquid core. Beyond the breakup length, the RT model was utilized in the conjunction with the $\mathrm{KH}$ model to predict the secondary breakup. Figure 3 presents the numerical grid designed to model the geometry of the engine, including maximum cells of 17960 and the number of cells varied according to different simulation conditions. The sector angle was 72 degrees. The parameters of the engine and different consumption of syngas utilized in this study are given in Table 4.

\section{Simulation Results and Discussion}

The effect of syngas addition on the combustion characteristics of diesel engine was calculated with the detailed mechanism, including ignition delay time and laminar flame speed. In order to study the effect of syngas addition on the combustion characteristics of the diesel fuel, six different proportions of syngas and diesel were utilized in the Chemkin software, as described in Table 5.

3.1. The Effect of Fuel Mixing Ratio on Ignition Delay Time and Laminar Flame Speed. The ignition delay time of diesel engine could be influenced by varieties of factors, including fuel cetane number, injection pressure, compression ratio, 
TABLE 1: The formation mechanism of $\mathrm{NO}_{x}$.

\begin{tabular}{|c|c|c|c|c|}
\hline & & $A_{f}$ & $n_{f}$ & $E_{f}$ \\
\hline (1) & $\mathrm{n}+\mathrm{no}=\mathrm{n} 2+\mathrm{o}$ & $3.5 E 13$ & 0.0 & $3.3 E 2$ \\
\hline (2) & $\mathrm{n}+\mathrm{o} 2=\mathrm{no}+\mathrm{o}$ & $2.65 E 12$ & 0.0 & $6.4 E 3$ \\
\hline (3) & $\mathrm{n}+\mathrm{oh}=\mathrm{no}+\mathrm{h}$ & $7.333 E 13$ & 0.0 & $1.12 E 3$ \\
\hline (4) & $\mathrm{n} 2 \mathrm{o}+\mathrm{o}=\mathrm{n} 2+\mathrm{o} 2$ & $1.4 E 12$ & 0.0 & $1.081 E 4$ \\
\hline (5) & $\mathrm{n} 2 \mathrm{o}+\mathrm{o}=2 \mathrm{no}$ & $2.9 E 13$ & 0.0 & $2.315 E 4$ \\
\hline (6) & $\mathrm{n} 2 \mathrm{o}+\mathrm{h}=\mathrm{n} 2+\mathrm{oh}$ & $4.4 E 14$ & 0.0 & $1.888 E 4$ \\
\hline (7) & $\mathrm{n} 2 \mathrm{o}+\mathrm{oh}=\mathrm{n} 2+\mathrm{ho} 2$ & $2.0 E 12$ & 0.0 & $2.106 E 4$ \\
\hline (8) & $\mathrm{n} 2 \mathrm{o}(+\mathrm{M})=\mathrm{n} 2+\mathrm{o}(+\mathrm{M})$ & $1.3 E 11$ & 0.0 & $5.962 E 4$ \\
\hline (9) & ho $2+$ no $=$ no $2+$ oh & $2.11 E 12$ & 0.0 & $-4.8 E 2$ \\
\hline (10) & $\mathrm{no}+\mathrm{o}+\mathrm{M}=\mathrm{no} 2+\mathrm{M}$ & $1.06 E 20$ & -1.41 & $0.0 E 0$ \\
\hline$(11)$ & $\mathrm{no} 2+\mathrm{o}=\mathrm{no}+\mathrm{o} 2$ & $3.9 E 12$ & 0.0 & $-2.4 E 2$ \\
\hline (12) & no $2+\mathrm{h}=$ no + oh & $1.32 E 14$ & 0.0 & $3.6 E 2$ \\
\hline
\end{tabular}

TABLE 2: Engine parameters.

\begin{tabular}{lc}
\hline Parameters & Description \\
\hline Power & $18 \mathrm{KW}$ \\
Bore & $85 \mathrm{~mm}$ \\
Stroke & $90 \mathrm{~mm}$ \\
Compression ratio & $17.1: 1$ \\
Injection system & common rail \\
Maximum injection pressure & $1,300 \mathrm{bar}$ \\
Size and number of nozzle holes & $0.17 \mathrm{~mm} \times 5$ \\
Spray angle & $142^{\circ}$ \\
Intake valve opening/closing & $13.5^{\circ} \mathrm{BTDC} / 46.5^{\circ} \mathrm{ABDC}$ \\
Exhaust valve opening/closing & $51.5^{\circ} \mathrm{BBDC} / 16.5^{\circ} \mathrm{ATDC}$ \\
\hline
\end{tabular}

Note. $\mathrm{ABDC}=$ after bottom dead center; $\mathrm{ATDC}=$ after top dead center; BBDC $=$ before bottom dead center; BTDC $=$ before top dead center.

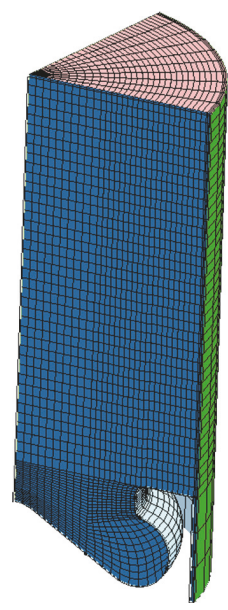

FIGURE 3: Sector meshes for engine simulation.

cylinder temperature, and other conditions, such as inlet air temperature, cooling water temperature, and fuel temperature. The cetane number was related to the autoignition temperature of diesel fuel. The injection pressure could reduce the mixing time of fuel and air. The compression ratio of the

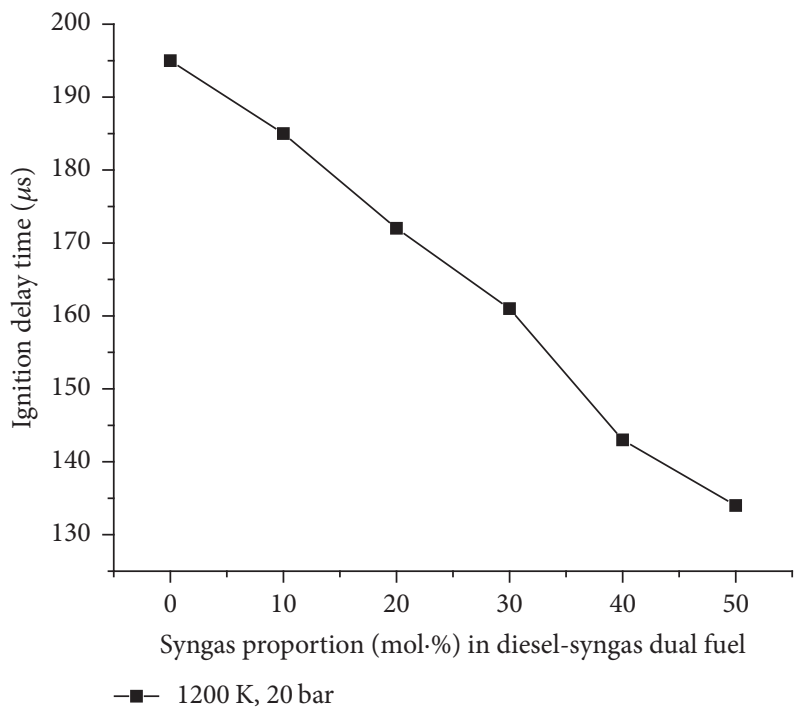

FIGURE 4: Ignition delay time for diesel-syngas dual fuel with different syngas proportion.

diesel engine becoming higher would make the distance between molecules become smaller. The closed homogeneous reaction model in Chemkin was utilized to predict the ignition delay time. This model was similar to the constant volume bomb, and the loss of heat and mass were ignored. The initial reaction temperature was $1200 \mathrm{~K}$ and the initial pressure was set to $20 \mathrm{~atm}$. In addition, the ignition delay time was calculated in the above 6 working conditions and the proportion of the syngas gradually increased from working condition 1 (pure diesel) to working condition 6 (50\% syngas by mol.). Therefore, the calculated data could present the influence of the addition of syngas on the ignition delay time of diesel-syngas mixture. The calculated results are presented in Figure 4.

It can be seen that, with the increase of syngas, the ignition delay time had a significant decreasing trend. Under the working condition 1 , no syngas was added, and the ignition delay time was $195 \mu$ s; under the working condition 6 with the 
TABLE 3: Diesel injection parameters.

\begin{tabular}{lccc}
\hline $\begin{array}{l}\text { Diesel injection pressure } \\
\text { (bar) }\end{array}$ & $\begin{array}{c}\text { Diesel injected amount } \\
\left(\mathrm{mm}^{3} / \text { cycle }\right)\end{array}$ & Energizing time (usec) & Related simulation angle at 1500 rpm (degree) \\
\hline 500 & 4 & 227.4 & 2.047 \\
500 & 6 & 302.6 & 2.723 \\
500 & 8 & 369.9 & 3.329 \\
750 & 4 & 172.5 & 1.553 \\
750 & 6 & 221.1 & 1.990 \\
750 & 8 & 273.5 & 2.462 \\
1000 & 4 & 139.6 & 1.256 \\
1000 & 6 & 174.7 & 1.572 \\
1000 & 8 & 209.8 & 1.889 \\
1250 & 4 & 122.5 & 1.102 \\
1250 & 6 & 147.9 & 1.331 \\
1250 & 8 & 174.7 & 1.572 \\
\hline
\end{tabular}

TABle 4: Parameters of the engine.

\begin{tabular}{lc}
\hline Parameters & Description \\
\hline $\begin{array}{l}\text { Syngas } \\
\text { composition }\end{array}$ & $50 \%$ vol. $\mathrm{H}_{2} / 30 \%$ vol. $\mathrm{CO} / 15 \%$ vol. $\mathrm{CO}_{2} / 5 \%$ vol. \\
$\begin{array}{l}\text { Syngas } \\
\text { consumption }\end{array}$ \\
$\begin{array}{l}\text { Start of diesel } \\
\text { injection }\end{array}$ \\
Maximum cells
\end{tabular}

syngas proportion of $50 \%$, the ignition delay time was $134 \mu \mathrm{s}$ and the ignition delay time was shortened by $33 \%$ when compared with the ignition delay time of the working condition 1 , which indicated that adding syngas can effectively reduce the ignition delay time of the mixed diesel-syngas fuels.

The speed of laminar flame was mainly related to the following factors, including fuel type, air-fuel ratio, temperature, and pressure. The flame speed model in Chemkin was adopted to calculate the laminar flame speed of the dieselsyngas dual fuel, and the simulation conditions were similar to the conditions of the model of ignition delay time. Figure 5 presents the laminar flame speed under the 6 working conditions.

Under working condition 1 , the content of the syngas was 0 , and the laminar flame speed was $44.437 \mathrm{~cm} / \mathrm{s}$. With the increase of the syngas content, the laminar flame speed became larger. Under working condition 6 , the content of the syngas was $50 \%$, and the laminar flame speed was $46.675 \mathrm{~cm} / \mathrm{s}$. The curve of the laminar flame speed had a gradual upward trend. Overall, the adding of syngas in the diesel fuel could reduce the ignition delay time and make the flame spread faster. Detailed calculations and analysis on the influence of syngas addition to diesel engine were conducted by Prakash et al. [33] who found that the ignition delay time in the cylinder was shortened and the flame speed rose with the increase of the syngas.

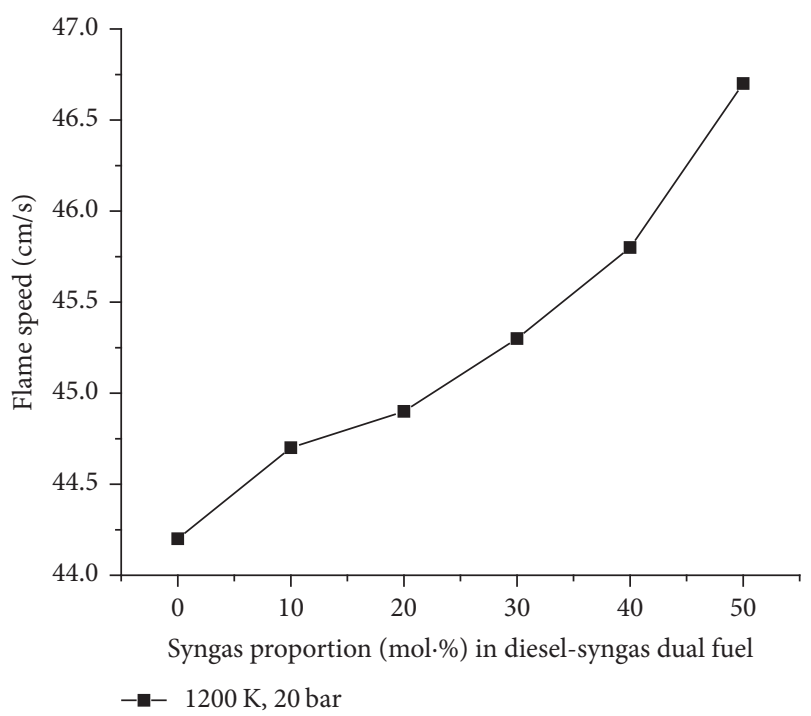

FIGURE 5: Laminar flame speed for dual fuel with different syngas proportion.

\subsection{Effect of Syngas Addition on the Optimal Diesel Injection} Timing. Due to the addition of syngas, the ignition delay time decreased and laminar flame speed increased for the diesel-syngas dual fuel. In comparison to the pure diesel combustion mode, it was necessary to change the diesel fuel injection time of the dual fuel mode so as to obtain an optimum power output. In the 3D simulation, only the diesel injection timing changed, while other parameters remained the same. The simulation conditions were as below: diesel injection timing was 0-4-12-16-20 degrees before TDC; the fuel injection quantity was $4 \mathrm{~mm}^{3} /$ cycle; the fuel injection pressure was 1000 bar; the engine speed was $1500 \mathrm{rpm}$; the constituents of the syngas were (by volume) $50 \% \mathrm{H}_{2}, 30 \%$ $\mathrm{CO}, 15 \% \mathrm{CO}_{2}$, and $5 \% \mathrm{CH}_{4}$. Figure 6 presents the effect of the start of injection (SOI) on the engine power. As shown in Figure 6, after the addition of syngas, the power of the engine 
TABLE 5: Proportion of diesel and syngas under different working conditions.

\begin{tabular}{lcccccc}
\hline Working condition & 1 & 2 & 3 & 4 & 5 & 6 \\
\hline Diesel (mol.\%) & 100 & 90 & 80 & 70 & 60 \\
Syngas (mol.\%) & 0 & 10 & 20 & 30 & 40 & 50 \\
\hline
\end{tabular}

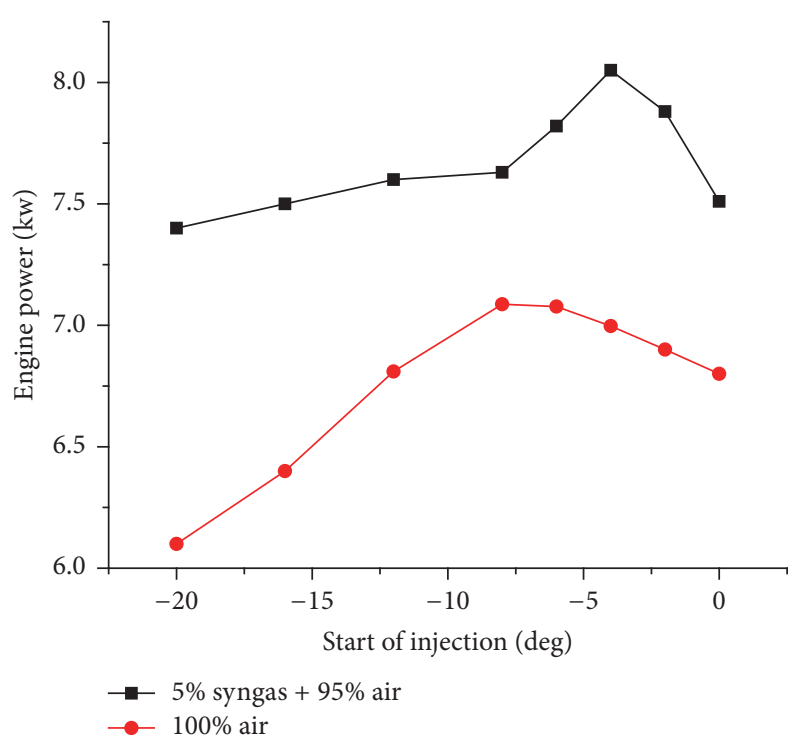

FIGURE 6: Effect of SOI on engine's power.

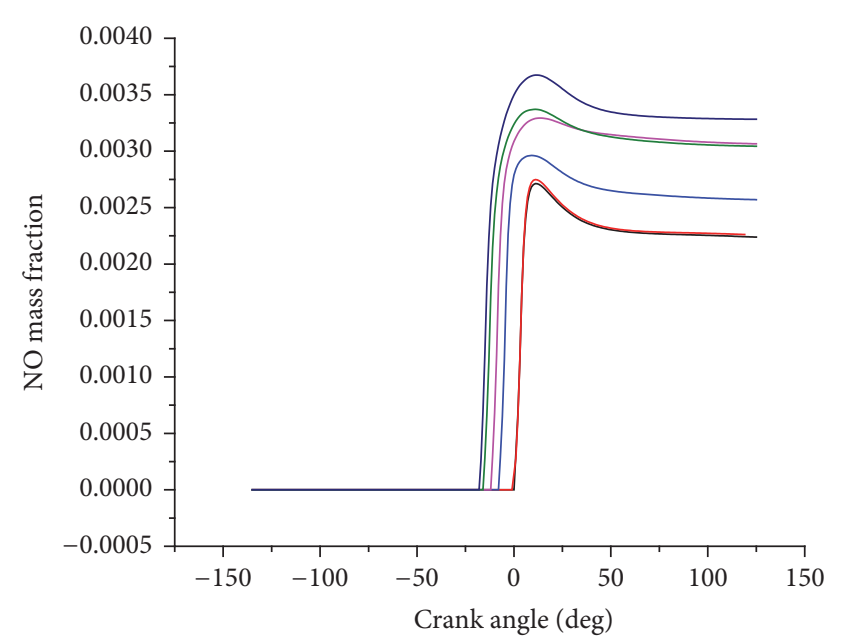

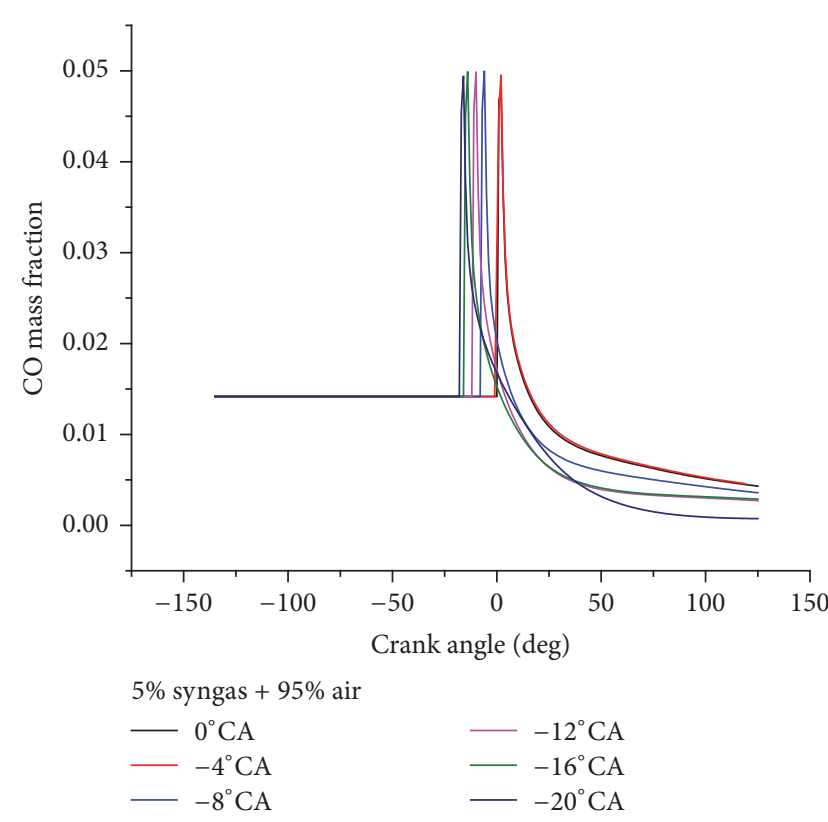

FIgURE 8: Effect of SOI on CO emission.

higher temperature and longer high-temperature duration could produce more nitrogen oxides. With the increase of diesel injection timing, the high-temperature duration increased, and the mass fraction of NO gradually rose. Figures 8 and 9 present the effect of diesel injection timing on the mass fraction of $\mathrm{CO}$ and $\mathrm{CO}_{2}$. As all simulations were under the condition of sufficient oxygen, the fuel can be fully burned. At the end of the simulation, the $\mathrm{CO}$ and $\mathrm{CO}_{2}$ mass fraction curves almost ended at the same position.

3.3. Effect of Syngas Injection Amount. To simulate the effect of syngas injection amount (Q_s), only the amount of syngas injection was changed. The consumption of syngas was $Q_{-} s=$ $0.25 \mathrm{~kg} / \mathrm{h}, 0.5 \mathrm{~kg} / \mathrm{h}, 0.75 \mathrm{~kg} / \mathrm{h}$, and $1 \mathrm{~kg} / \mathrm{h}$, while other parameters in the simulation model remained the same. The diesel injection timing was 7.5 degrees before TDC and the diesel injection amount was $0.04 \mathrm{~mm}^{3} /$ cycle. Figure 10 presents the effects of different amounts of syngas injection on the cylinder pressure. It could be observed that ignition time remained unchanged. The peak value of the cylinder pressure rose with the increase of the syngas injection amount. The increasing of pressure was ascribed to the following reasons: (1) increase in the amount of syngas would increase the amount of fuel in the cylinder, although the heat released by the syngas was relatively small in comparison to that of the injected diesel; (2) syngas with excellent characteristics of combustion could promote the combustion of diesel oil, increased, while compared to the pure diesel mode, after syngas addition, the maximum engine power is increased from $7.08 \mathrm{kw}$ at 8 degrees before TDC to $8.05 \mathrm{kw}$ at 4 degrees before TDC.

Figure 7 shows the influence of diesel injection timing on the mass fraction of NO. The formation of nitrogen oxides had a strong connection to the cylinder temperature, and

\section{0}

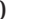




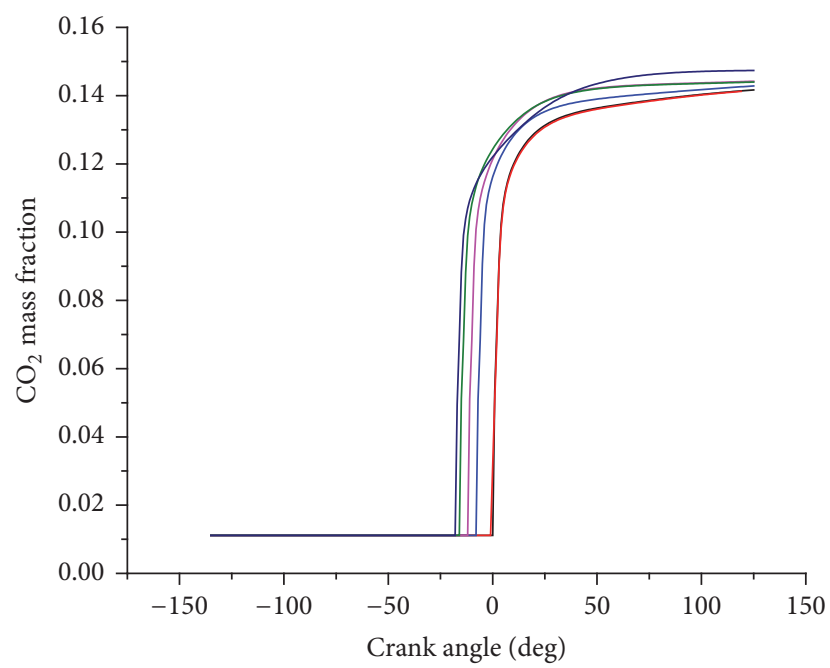

$5 \%$ syngas $+95 \%$ air

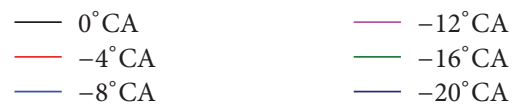

Figure 9: Effect of SOI on $\mathrm{CO}_{2}$ emission.

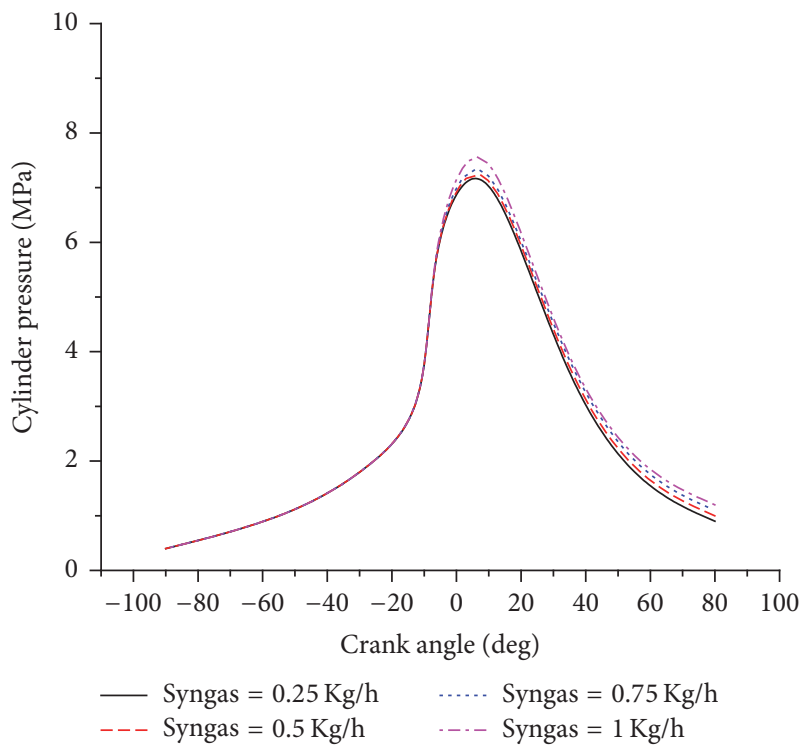

FIGURE 10: Effect of syngas addition on cylinder pressure.

accelerating the speed of flame propagation in cylinder, as well as enhancing the combustion efficiency.

Figure 11 presents the effect of syngas addition on nitrogen oxides. With the increase of syngas, the mass fraction of nitrogen oxides decreased gradually. Although syngas addition caused a higher temperature in the cylinder and higher temperatures generated more $\mathrm{NO}_{x}$, syngas could make the combustion of diesel-air mixture faster, reducing the duration time of higher temperature and decreasing the $\mathrm{NO}_{x}$ emission. Figure 12 presents the effect of the syngas addition on the carbon oxides. The increase of syngas means that more fuel was burning, and the mass fraction of carbon

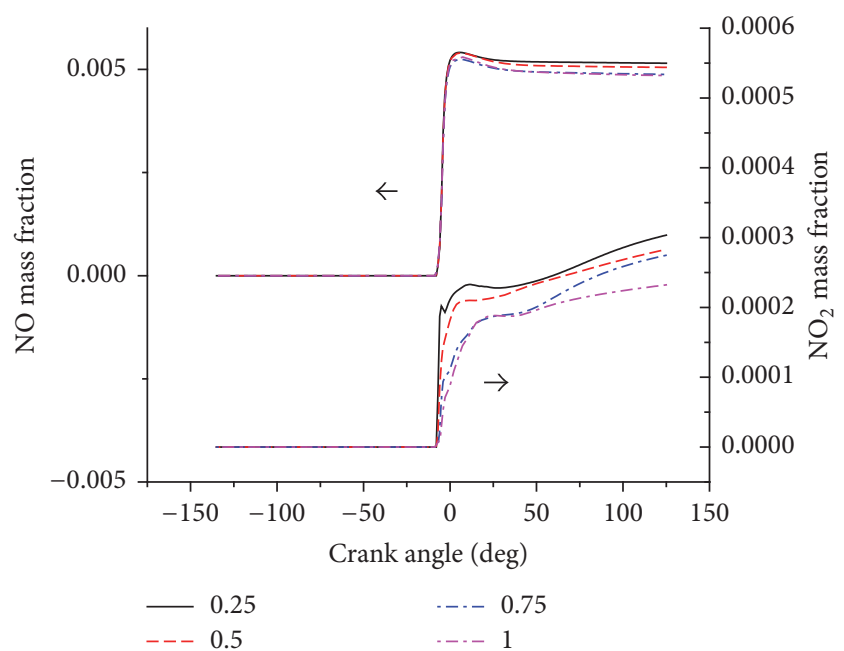

FIGURE 11: Effect of syngas addition on $\mathrm{NO}_{x}$ emission.

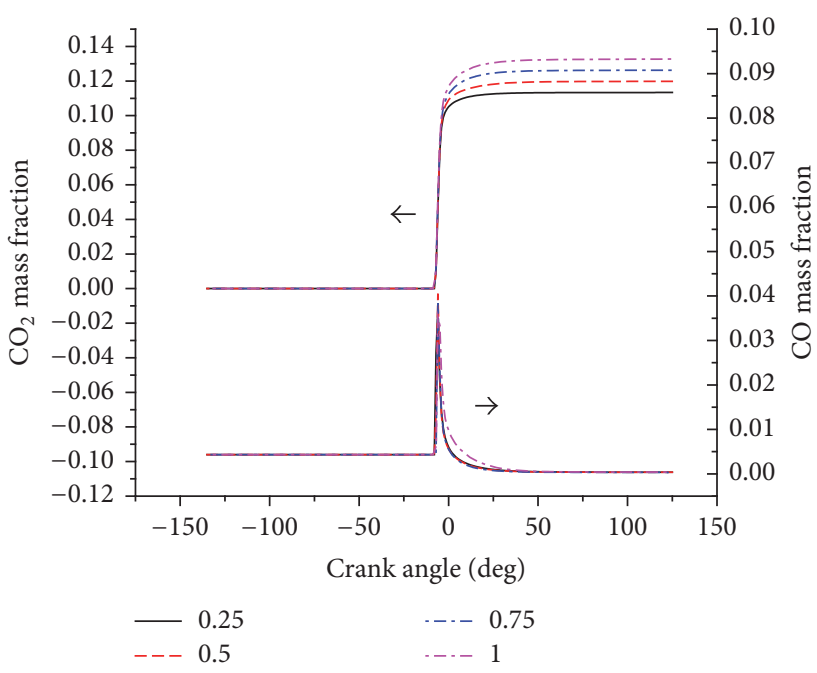

FIGURE 12: Effect of syngas addition on $\mathrm{CO}$ and $\mathrm{CO}_{2}$ emission.

dioxide increased. The simulation model worked at the fuel lean condition; the carbon monoxide was almost fully oxidized, and the addition of syngas had no effect on the carbon monoxide.

The spatial distributions of temperature and $\mathrm{OH}$ mass fraction with/without syngas addition are compared in Figures 13 and 14 . The diesel injection timing was $-8 \mathrm{CAD}$ and the syngas injection amount was $0.25 \mathrm{~kg} / \mathrm{h}$. With the addition of syngas, high-temperature area and high $\mathrm{OH}$ mass fraction area were greater than the pure diesel mode.

3.4. Experimental Results and Discussion. Figure 15 shows the comparison of the pressure curve acquired from experiment and simulation. The comparison reported in Figure 15 is obtained from the engine with the following conditions: diesel injection advance $=12$ degrees' crank angle BTDC, diesel amount injected $=6 \mathrm{~mm}^{3} /$ cycle, the syngas injected pressure $=3 \mathrm{bar}$, and the engine speed is $1500 \mathrm{rpm}$. This figure shows that the simulation matched with the experimental 

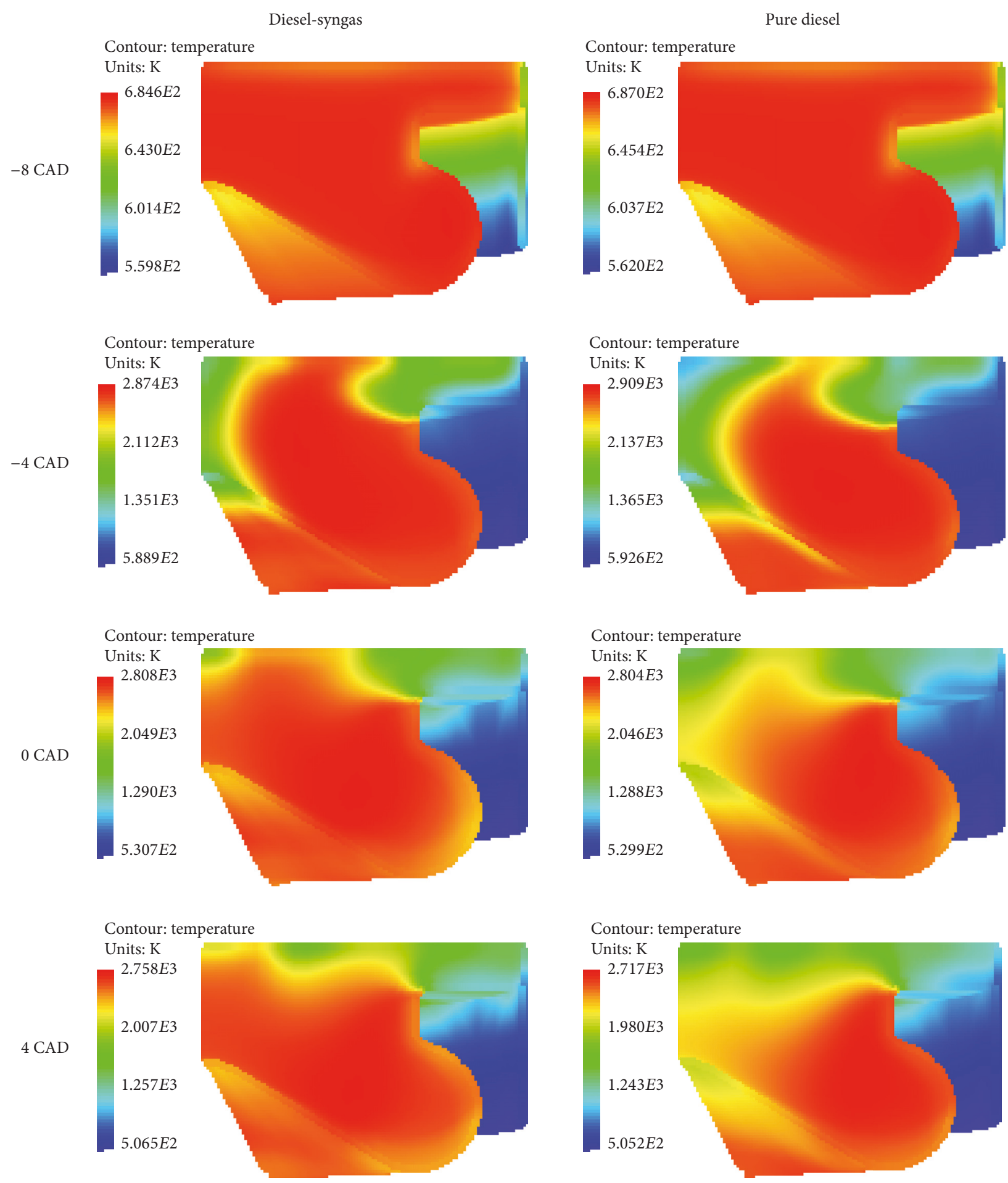

FigURE 13: Spatial distribution of temperature.

data. Hence the simulation model can be applied to predict the combustion and emission characteristics of the dieselsyngas dual fuel engine.

The diesel consumption remained constant under the initial engine power output of $12 \mathrm{kw}$ and the syngas addition gradually increased. Figures 16 and 17 present the performance of combustion in the cylinder and Figures 18-20 describe the emissions. Brake thermal efficiency can be calculated by the ratio between the engine power output and the total lower heating value of the diesel and syngas. The 
Diesel-syngas

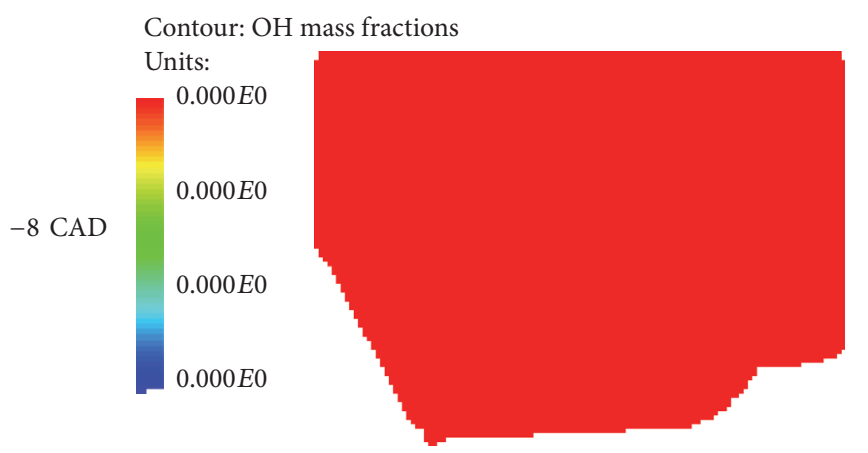

Contour: $\mathrm{OH}$ mass fractions

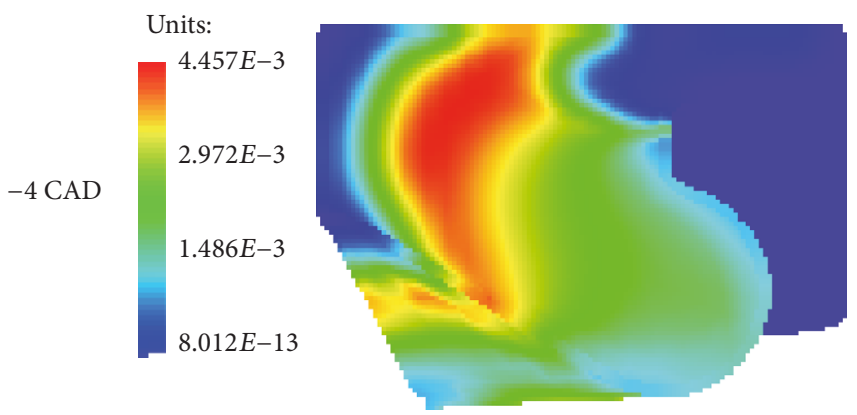

Contour: $\mathrm{OH}$ mass fractions

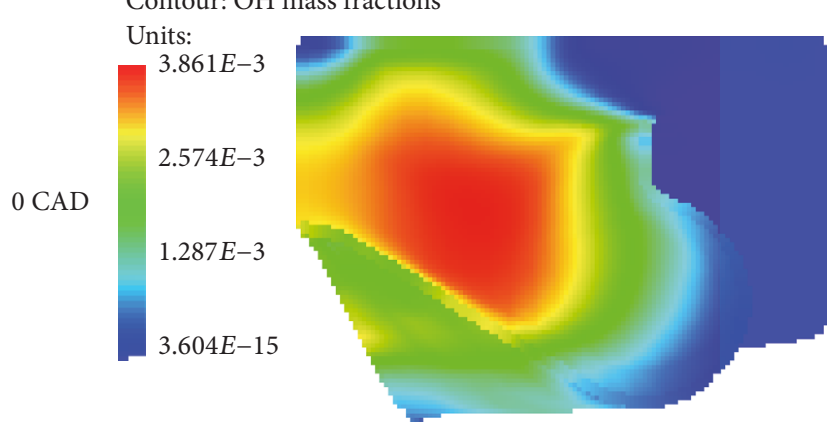

Contour: $\mathrm{OH}$ mass fractions

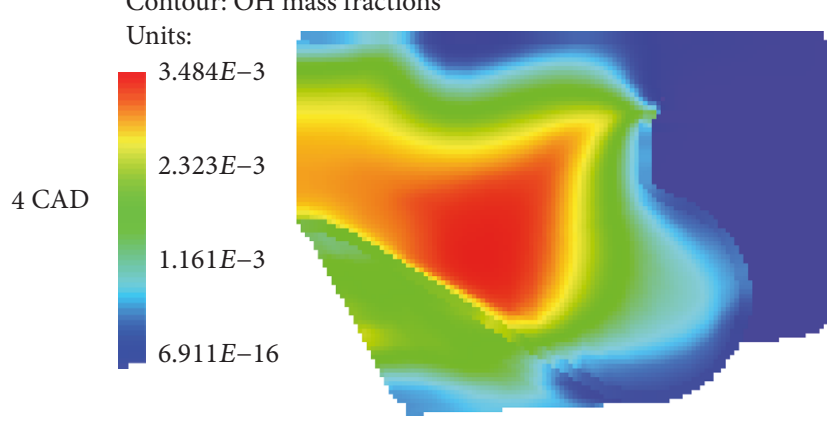

Pure diesel

Contour: $\mathrm{OH}$ mass fractions

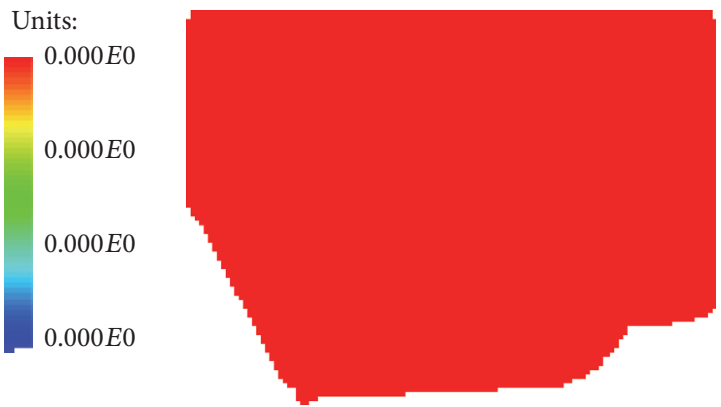

Contour: $\mathrm{OH}$ mass fractions

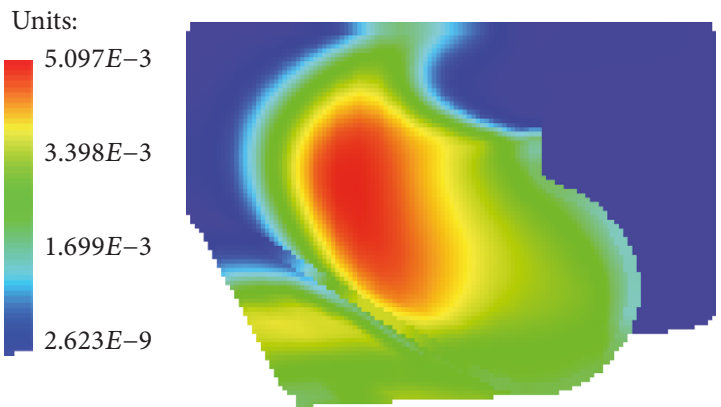

Contour: $\mathrm{OH}$ mass fractions

Units:

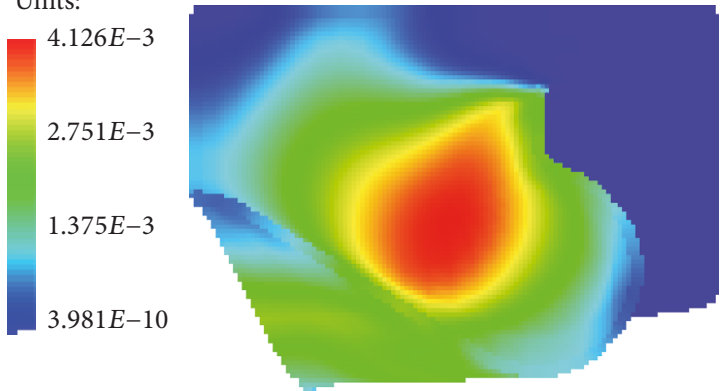

Contour: $\mathrm{OH}$ mass fractions

Units:

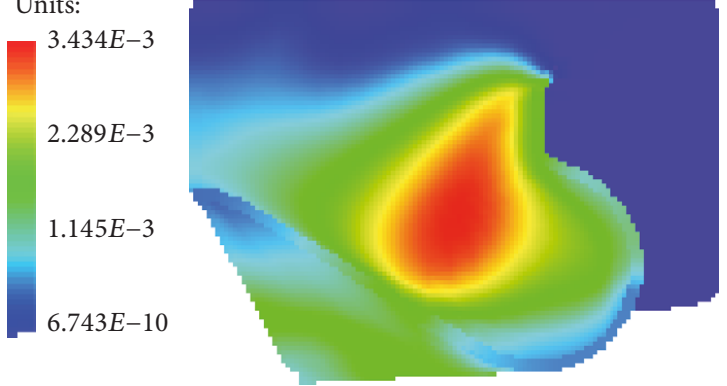

FIGURE 14: Spatial distribution of $\mathrm{OH}$ mass fraction. 


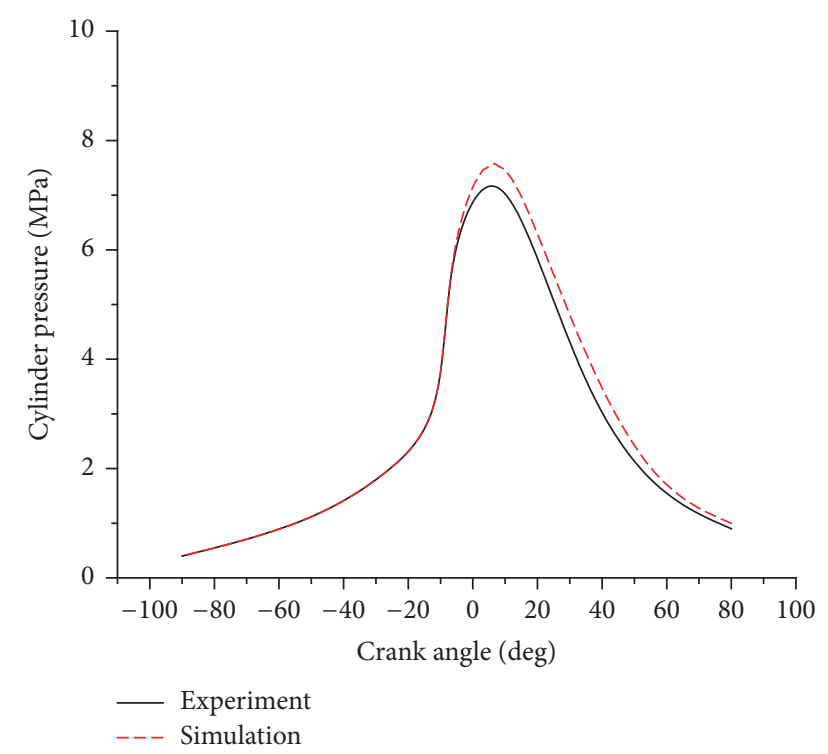

FIGURE 15: Comparison of predicted and measured profiles of pressure.

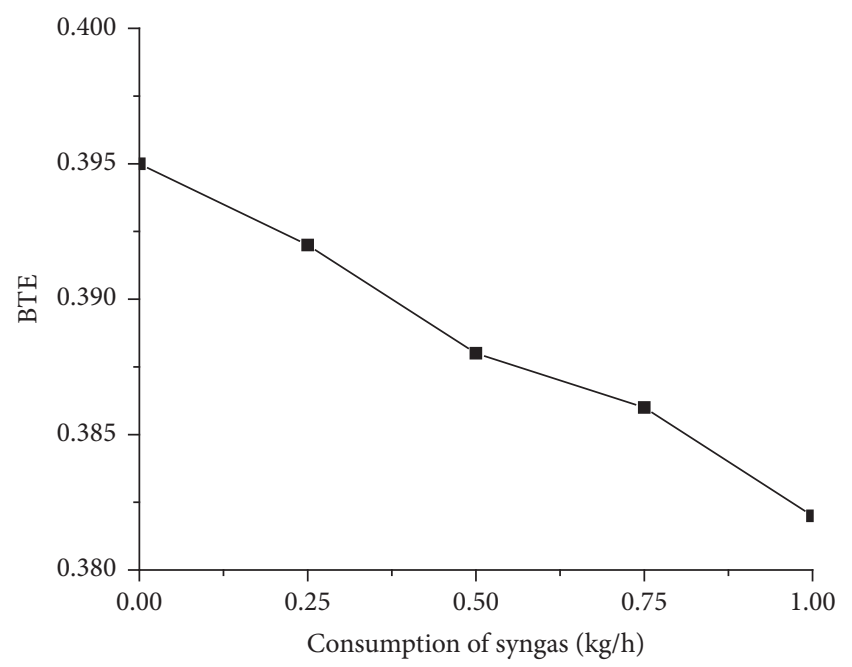

Figure 16: Effect of syngas addition on BTE.

calculation of brake thermal efficiency is presented in the following equation:

brake thermal efficiency (BTE)

$$
=\frac{\text { brake power of engine }}{m_{\text {diesel }} * \mathrm{LHV}_{\text {diesel }}+m_{\text {syngas }} * \mathrm{LHV}_{\text {syngas }}},
$$

where $m_{\text {diesel }}$ is the consumption of diesel, $m_{\text {syngas }}$ is the consumption of syngas, $\mathrm{LHV}_{\text {diesel }}$ is the lower heating value of diesel, and $\mathrm{LHV}_{\text {syngas }}$ is the lower heating value of syngas.

The calculated BTE is presented in Figure 16, showing that, with the increase of syngas, the brake thermal efficiency decreased. The results of this experiment, contradicting with the simulation result, were mainly ascribed to the following two reasons: (1) with the increase of the amount of syngas,

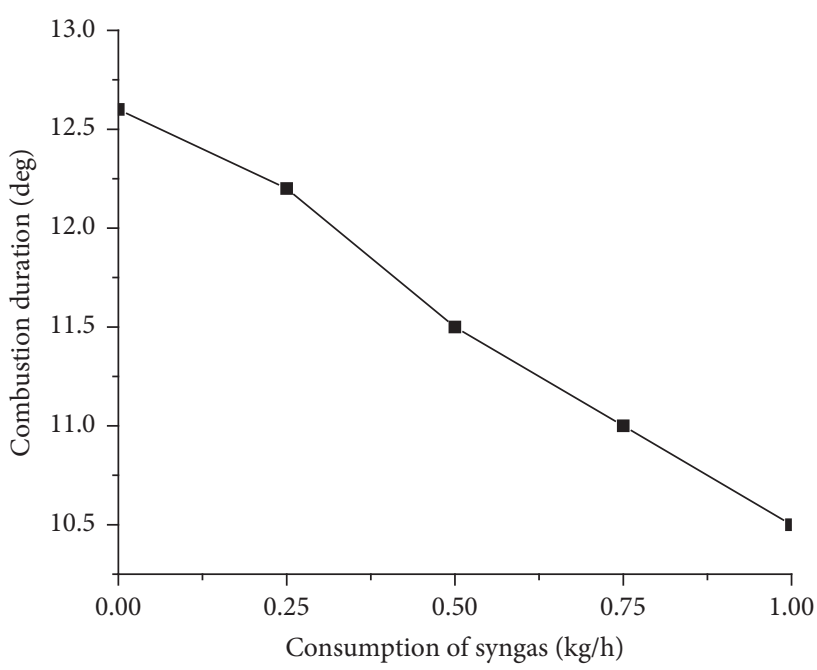

FIGURE 17: Effect of syngas addition on combustion duration.

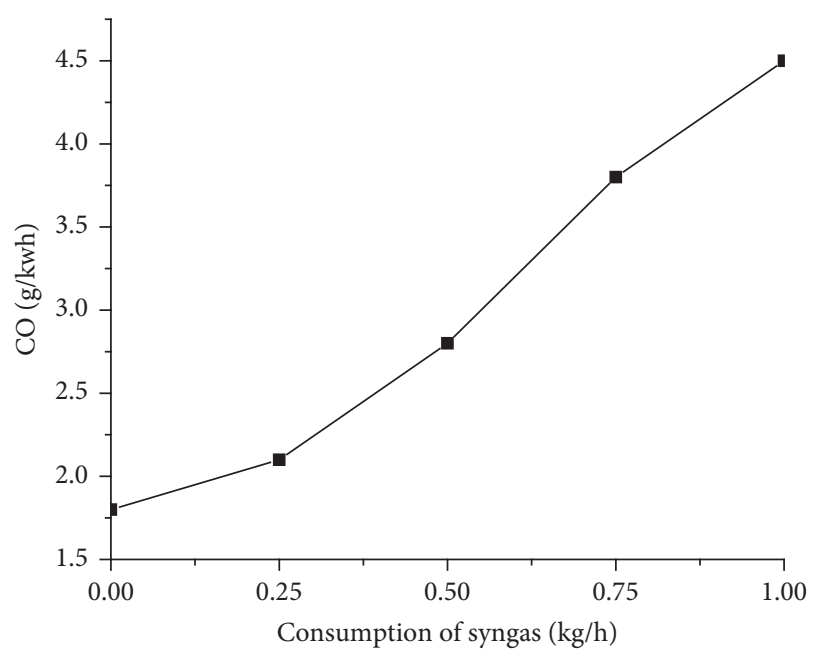

Figure 18: Effect of syngas addition on CO emission.

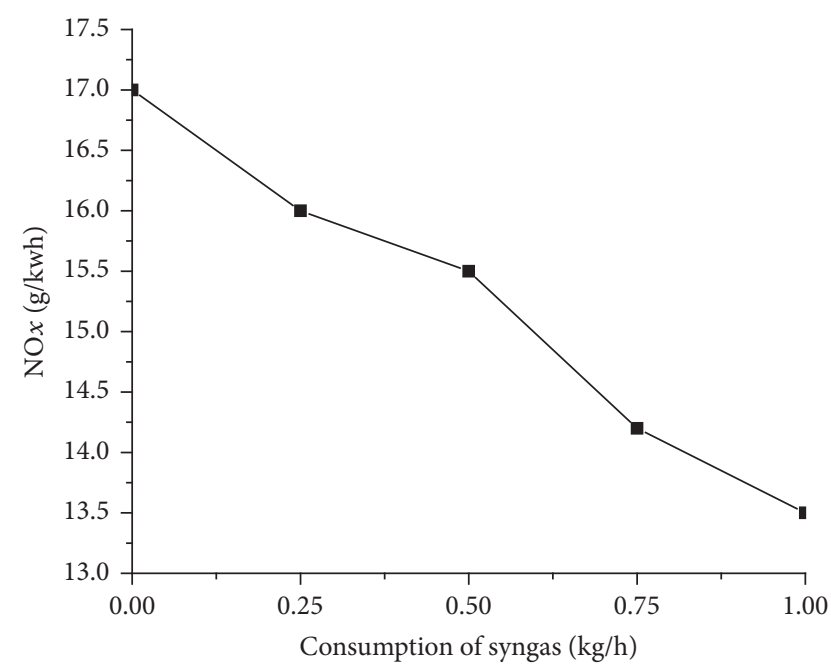

Figure 19: Effect of syngas addition on $\mathrm{NO}_{x}$ emission. 


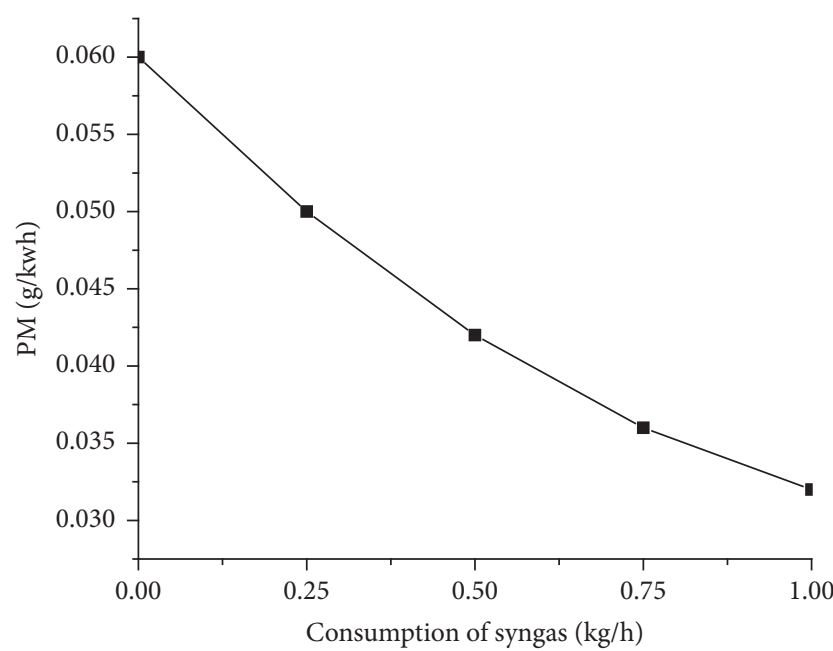

FIGURE 20: Effect of syngas addition on PM emission.

the amount of syngas escaping from the engine cylinder increased, since the 3D simulation was a closed system with no mass loss; (2) higher cylinder temperature could lead to full consumption of syngas. When the output power of the engine was $12 \mathrm{KW}$, the cylinder temperature was at a relatively high level, and the addition of syngas did not effectively improve the cylinder temperature. It can be predicted that if the initial load of the engine is low, the decreasing trend of BTE will slow down.

From the intake valve closing to the exhaust valve opening, the cylinder could be approximately treated as a closed system. The heat releasing rate could be calculated with the thermodynamic law and the cylinder pressure curve [34]. The combustion duration of the air-fuel mixture was defined at the beginning of the combustion to the time of $90 \%$ heat releasing. The effect of the increase of the syngas addition on the combustion duration is presented in Figure 17. It can be seen that, with the increase of syngas addition, the combustion duration was shortened, which was consistent with the prediction of the ignition delay time and laminar flame speed.

Figures 18-20 present the effect of syngas addition on emissions. The $\mathrm{CO}$ emission increased rapidly with the increase of syngas addition. This trend has also been expressed in the study conducted by Bedoya et al. [35]. The main reason was the escape of unburned $\mathrm{CO}$ in the syngas. The reduction of particulate matter emission was mainly due to the following reason: for the same engine power output, the combustion duration was shortened after the addition of syngas. $\mathrm{NO}_{x}$ emission reduced drastically. As for the same engine power output, the addition of syngas resulted in a lower flame temperature and a higher efficiency of combustion in the cylinder $[5,36]$.

\section{Conclusions}

In this paper, the combustion characteristics of a diesel engine with syngas addition were calculated. A reduced mechanism for the diesel-syngas dual fuel was constructed by direct relation graph and sensitivity analysis with the detailed mechanism of $\mathrm{n}$-heptane by the Lawrence Livermore Laboratory. The calculation of Chemkin with the detailed mechanism indicates that the addition of syngas could reduce the ignition delay time and increase laminar flame speed. These combustion characteristics had a promoting effect on the engine's lean burn condition and emission reduction. Compared with the heavy load, more syngas can be added when the engine was running at light load. Due to the lower calorific value of the syngas, to maintain the power output of diesel engine, the addition of syngas should be reduced. The nitrogen oxides and the particulate matter of the diesel engine could be effectively reduced by the syngas addition. The addition of syngas would slightly reduce the brake thermal efficiency of the engine and increase carbon monoxide emission. Taking into account the fact that the partial power output of the engine is the contribution of the combustion of syngas and the renewable, nonpolluting characteristics of the syngas, the diesel-syngas dual fuel model is still very valuable.

\section{Conflicts of Interest}

The authors declare that there are no conflicts of interest regarding the publication of this paper.

\section{Acknowledgments}

The authors are grateful for the contributions of Professor A. P. Carlucci and financial support of Shanghai Maritime University.

\section{References}

[1] G. Kolb, S. Keller, D. Tiemann, K.-P. Schelhaas, J. Schürer, and O. Wiborg, "Design and operation of a compact microchannel $5 \mathrm{~kW}_{\text {el,net }}$ methanol steam reformer with novel $\mathrm{Pt} / \mathrm{In}_{2} \mathrm{O}_{3}$ catalyst for fuel cell applications," Chemical Engineering Journal, vol. 207-208, pp. 388-402, 2012.

[2] G.-G. Park, D. J. Seo, S.-H. Park, Y.-G. Yoon, C.-S. Kim, and W.-L. Yoon, "Development of microchannel methanol steam reformer," Chemical Engineering Journal, vol. 101, no. 1-3, pp. 8792, 2004.

[3] S. Cimino, G. Mancino, and L. Lisi, "Ethane catalytic partial oxidation to ethylene with sulphur and hydrogen addition over $\mathrm{Rh}$ and Pt honeycombs," Catalysis Today, vol. 228, pp. 131-137, 2014.

[4] G. Carotenuto, A. Kumar, J. Miller, A. Mukasyan, E. Santacesaria, and E. E. Wolf, "Hydrogen production by ethanol decomposition and partial oxidation over copper/copper-chromite based catalysts prepared by combustion synthesis," Catalysis Today, vol. 203, pp. 163-175, 2013.

[5] N. N. Mustafi, R. R. Raine, and S. Verhelst, "Combustion and emissions characteristics of a dual fuel engine operated on alternative gaseous fuels," Fuel, vol. 109, pp. 669-678, 2013.

[6] B. B. Sahoo, N. Sahoo, and U. K. Saha, "Effect of $\mathrm{H}_{2}$ : CO ratio in syngas on the performance of a dual fuel diesel engine operation," Applied Thermal Engineering, vol. 49, pp. 139-146, 2012. 
[7] B. B. Sahoo, N. Sahoo, and U. K. Saha, "Dual fuel performance studies of a small diesel engine using green fuels," Applied Mechanics \& Materials, vol. 110, pp. 2101-2108, 2011.

[8] B. B. Sahoo, U. K. Saha, and N. Sahoo, "Theoretical performance limits of a syngas-diesel fueled compression ignition engine from second law analysis," Energy, vol. 36, no. 2, pp. 760-769, 2011.

[9] A. P. Carlucci, A. Ficarella, and D. Laforgia, "Potentialities of a common rail injection system for the control of dual fuel biodiesel-producer gas combustion and emissions," Journal of Energy Engineering, vol. 140, no. 3, 2014.

[10] U. Azimov, M. Okuno, K. Tsuboi et al., "Multidimensional CFD simulation of syngas combustion in a micro-pilot-ignited dualfuel engine using a constructed chemical kinetics mechanism," Fuel \& Energy Abstracts, vol. 36, no. 21, pp. 13793-13807, 2011.

[11] J. J. Hernández, G. Aranda, J. Barba, and J. M. Mendoza, "Effect of steam content in the air-steam flow on biomass entrained flow gasification," Fuel Processing Technology, vol. 99, pp. 43-55, 2012.

[12] J. J. Hernández, M. Lapuerta, and J. Barba, "Effect of partial replacement of diesel or biodiesel with gas from biomass gasification in a diesel engine," Energy, vol. 89, article no. 7768, pp. 148-157, 2015.

[13] F. Zhang, R. Yu, and X. S. Bai, "Detailed numerical simulation of syngas combustion under partially premixed combustion engine conditions," International Journal of Hydrogen Energy, vol. 37, no. 22, pp. 17285-17293, 2012.

[14] C. Dong, Q. Zhou, Q. Zhao, Y. Zhang, T. Xu, and S. Hui, “Experimental study on the laminar flame speed of hydrogen/carbon monoxide/air mixtures," Fuel, vol. 88, no. 10, pp. 1858-1863, 2009.

[15] G. Li, Z. Zhang, F. You et al., "A novel strategy for hydrousethanol utilization: demonstration of a spark-ignition engine fueled with hydrogen-rich fuel from an onboard ethanol/steam reformer," International Journal of Hydrogen Energy, vol. 38, no. 14, pp. 5936-5948, 2013.

[16] C. Ji, X. Dai, B. Ju et al., "Improving the performance of a sparkignited gasoline engine with the addition of syngas produced by onboard ethanol steaming reforming," International Journal of Hydrogen Energy, vol. 37, no. 9, pp. 7860-7868, 2012.

[17] X. Dai, C. Ji, S. Wang, C. Liang, X. Liu, and B. Ju, "Effect of syngas addition on performance of a spark-ignited gasoline engine at lean conditions," International Journal of Hydrogen Energy, vol. 37, no. 19, pp. 14624-14631, 2012.

[18] T. Lu and C. K. Law, "On the applicability of directed relation graphs to the reduction of reaction mechanisms," Combustion and Flame, vol. 146, no. 3, pp. 472-483, 2006.

[19] T. F. Lu and C. K. Law, "A directed relation graph method for mechanism reduction," Proceedings of the Combustion Institute, vol. 30, no. 1, pp. 1333-1341, 2005.

[20] M. Mehl, W. J. Pitz, M. Sjöberg, and J. E. Dec, "Detailed kinetic modeling of low-temperature heat release for PRF fuels in an HCCI engine," SAE Technical Papers, pp. 318-323, 2009.

[21] M. Mehl, W. J. Pitz, C. K. Westbrook, and H. J. Curran, "Kinetic modeling of gasoline surrogate components and mixtures under engine conditions," Proceedings of the Combustion Institute, vol. 33, no. 1, pp. 193-200, 2011.

[22] J. Li, Z. Zhao, A. Kazakov, M. Chaos, F. L. Dryer, and J. I. Scire Jr., "A comprehensive kinetic mechanism for $\mathrm{CO}, \mathrm{CH}_{2} \mathrm{O}$, and $\mathrm{CH}_{3} \mathrm{OH}$ combustion," International Journal of Chemical Kinetics, vol. 39, no. 3, pp. 109-136, 2007.
[23] T. Lu and C. K. Law, "Toward accommodating realistic fuel chemistry in large-scale computations," Progress in Energy and Combustion Science, vol. 35, no. 2, pp. 192-215, 2009.

[24] T. F. Lu and C. K. Law, "Strategies for mechanism reduction for large hydrocarbons: n-heptane," Combustion \& Flame, vol. 154, no. 1-2, pp. 153-163, 2008.

[25] J. A. Miller and C. T. Bowman, "Mechanism and modeling of nitrogen chemistry in combustion," Progress in Energy and Combustion Science, vol. 15, no. 4, pp. 287-338, 1989.

[26] H. Wang, R. D. Reitz, M. F. Yao et al., "Development of an $\mathrm{n}$-heptane-n-butanol-PAH mechanism and its application for combustion and soot prediction," Combustion \& Flame, vol. 160, no. 3, pp. 504-519, 2013.

[27] J. Buckmaster, The Mathematical Theory of Combustion and Explosions, Consultants Bureau, 1985.

[28] C. P. Fenimore, "Studies of fuel-nitrogen species in rich flame gases," Symposium (International) on Combustion, vol. 17, no. 1, pp. 661-670, 1979.

[29] J. Wolfrum, "Bildung von Stickstoffoxiden bei der Verbrennung," Chemie Ingenieur Technik, vol. 44, no. 10, pp. 656-659, 1972.

[30] B. Gradon, "The role of nitrous oxide in the mechanism of thermal nitric oxide formation within flame temperature range," Combustion Science \& Technology, vol. 125, no. 1, pp. 159_ 180, 1997.

[31] Z. Y. Han and R. D. Reitz, "A temperature wall function formulation for variable-density turbulent flows with application to engine convective heat transfer modeling," International Journal of Heat \& Mass Transfer, vol. 40, no. 3, pp. 613-625, 1997.

[32] J. C. Beale and R. D. Reitz, "Modeling spray atomization with the Kelvin-Helmholtz/Rayleigh-Taylor hybrid model," Atomization and Sprays, vol. 9, no. 6, pp. 623-650, 1999.

[33] G. Prakash, A. Ramesh, and A. B. Shaik, "An approach for estimation of ignition delay in a dual fuel engine," SAE Technical Papers, vol. 1, no. 1, pp. 1-7, 1999.

[34] M. Lapuerta, R. Ballesteros, and J. R. Agudelo, "Effect of the gas state equation on the thermodynamic diagnostic of diesel combustion," Applied Thermal Engineering, vol. 26, no. 14-15, pp. 1492-1499, 2006.

[35] I. D. Bedoya, A. A. Arrieta, and F. J. Cadavid, "Effects of mixing system and pilot fuel quality on diesel-biogas dual fuel engine performance," Bioresource Technology, vol.100, no. 24, pp. 66246629, 2009.

[36] S. H. Yoon and C. S. Lee, "Experimental investigation on the combustion and exhaust emission characteristics of biogasbiodiesel dual-fuel combustion in a CI engine," Fuel Processing Technology, vol. 92, no. 5, pp. 992-1000, 2011. 


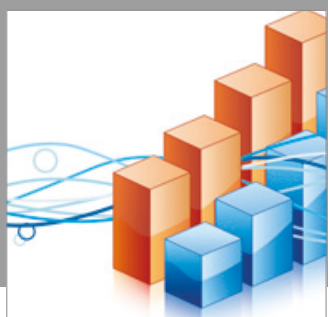

Advances in

Operations Research

vatersals

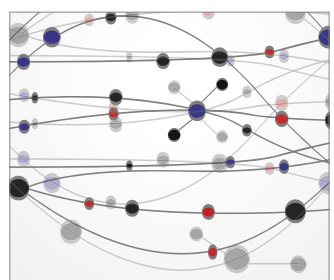

\section{The Scientific} World Journal
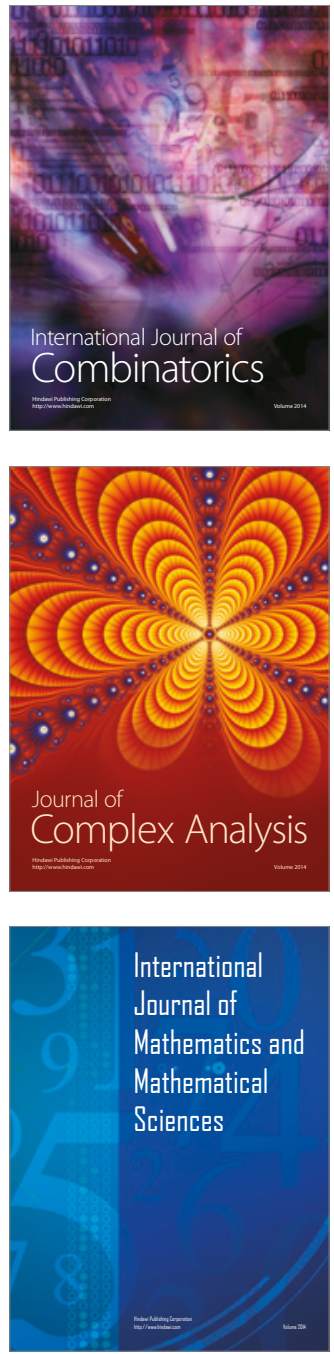
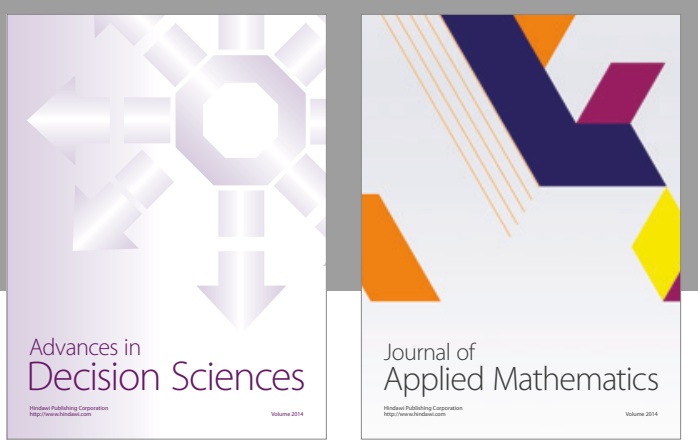

Algebra

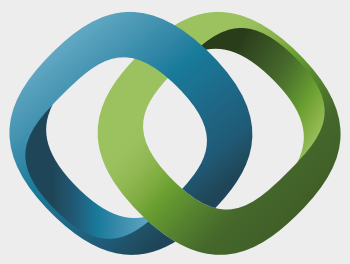

\section{Hindawi}

Submit your manuscripts at

https://www.hindawi.com
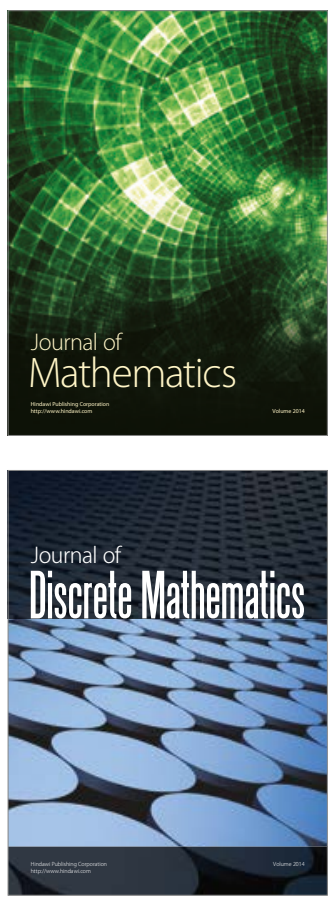

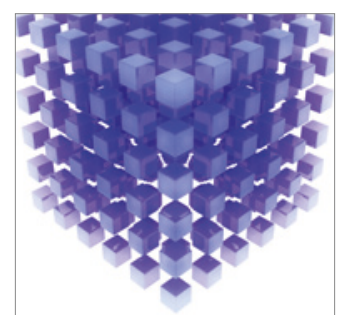

Mathematical Problems in Engineering
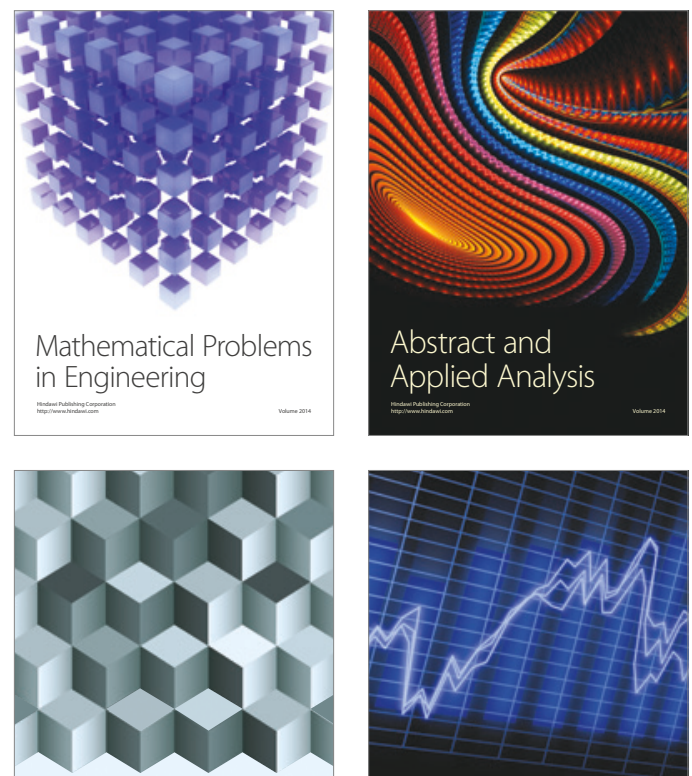

Journal of

Function Spaces

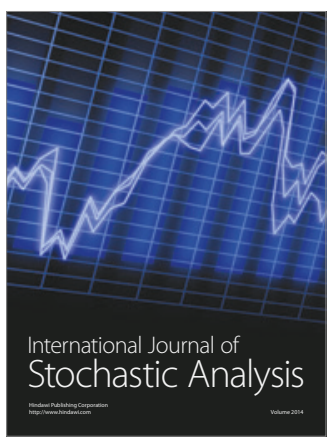

Probability and Statistics
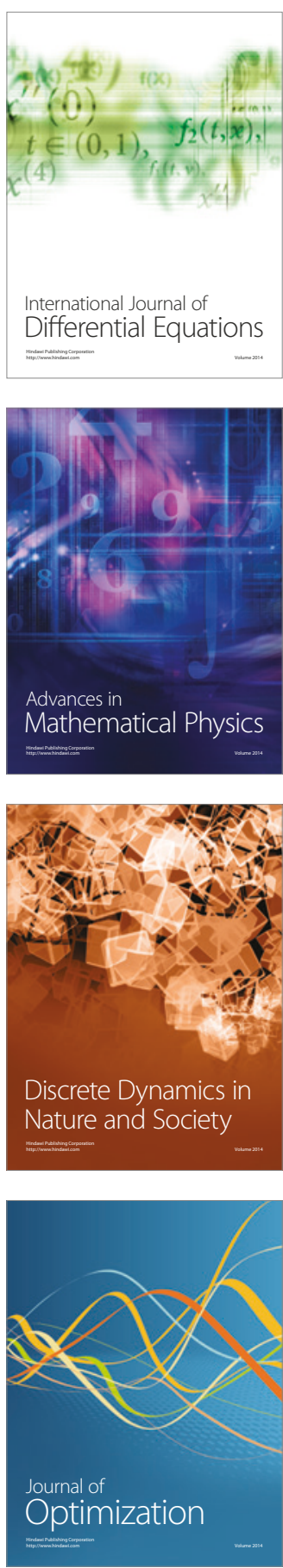